\title{
The Appeal of Technical Education in Tough Times: A Comparison of the Toronto and Windsor Experiences, 1890-1930
}

\author{
Kathleen Yolande Sharman and Larry Glassford \\ University of Windsor
}

\begin{abstract}
:
This paper compares the establishment of two pioneering technical schools in Ontario - the Toronto Technical School in the 1890s, and Windsor-Walkerville Technical School in the 1920s. Though separated by geography and chronological era, there are significant similarities in their development, from idealistic schemes in the minds of a few visionaries to bricks-andmortar reality as thriving stand-alone technical high schools. The analysis, while based on primary documents from the historical period, utilizes both the classical interpretation of Robert Stamp and the work of subsequent revisionists. An examination of evolving educational policy and changes in regional economic geography helps to situate this comparative institutional study in a broader interpretive perspective. The conclusion, that each school in its time was innovative, popular and respected, will provide valuable historical context for current debates about the appropriate role of technical schools in public education.
\end{abstract}

\section{RÉSUMÉ :}

Cet article compare l'établissement de deux écoles techniques pionnières en Ontario, la Toronto Technical School dans les années 1890 et la Windsor-Walkerville Technical School dans les années 1920. Bien qu'éloignées par la géographie et dans le temps, on constate des similitudes dans le développement de ces institutions : un même idéal porté par quelques visionnaires et l'importance accordée à l'architecture propre à ces écoles techniques. Quoique basée sur des documents d'époque, cette analyse s'appuie sur l'interprétation classique de Robert Stamp ainsi que sur les travaux subséquents d'historiens révisionnistes. L'étude de l'évolution des politiques d'éducation et des changements dans chacune des économies régionales permet de situer la comparaison de ces institutions dans une plus large perspective. La conclusion étant que chacune des écoles a, de son temps, été innovatrice, populaire et respectée, fournit des arguments historiques valables dans les débats actuels quant au rôle spécifique des écoles techniques dans l'éducation publique. 
The need for technical education in the publicly-funded schools of Ontario was not always self-evident. For much of the nineteenth century, it was assumed that such training would be provided in the workplace, largely through apprenticeship programs. With the advent of industrialization and urbanization, however, the old system of on-the-job craft training began to break down. ${ }^{1}$ Increasing pressure was brought to bear upon governments, both provincial and municipal, to provide appropriate instruction in public schools so that young people might find acceptable jobs in the new economy, and employers might draw upon a suitably-prepared labour pool. This paper will examine the establishment of two pioneering technical schools - the Toronto Technical School (TTS) in the 1890s, and Windsor-Walkerville Technical School (WWTS) in the 1920 s - in a comparative perspective. While local conditions played their part, certain overriding features seem to link the two schools, despite their separation by geography and chronological era.

\section{A Brief Literature Review}

According to the pioneering work of Robert $S$ tamp ${ }^{2}$, the main impetus for the rise of technical and vocational education in Ontario between the late nineteenth to early twentieth century was economic. As the rise of industrialization altered the modes of production, the manufacturers required a labour force trained in the new skills, and socialized to the realities of factory production. Traditional apprenticeship was in decline. The popular solution appeared to be utilizing the publicly-funded schools. The interests of working-class parents who desired employment opportunities for their children coincided with the interests of capitalists seeking a qualified work force. At the same time, Stamp noted the impact of educational reformers associated with the New Education Movement, who favoured a broader education than the classical liberal approach prevailing in Ontario's collegiate institutes. The end result, according to Stamp, was a significant trend toward technical education at the secondary level in Ontario that enjoyed broad-based public support.

Revisionist historians have sought to paint a more nuanced picture of this movement to provide technical education through the publicly-funded school system. T.R. Morrison, ${ }^{3}$ for instance, strongly suggested that the various forms of industrial education were primarily motivated by reasons other than economic growth and equality of opportunity. Morrison connected the growing support for technical education to an urban-oriented conservative reform movement concerned with controlling the behaviour of the working poor, and incidentally, sustaining socio-economic inequality, which tended to benefit those same self-styled reformers. Goodson and Dowbiggin, ${ }^{4}$ basing their findings on a case study of the London (Ontario) Technical School, noted that a stout resistance to technical education was mounted by local interests who feared the diversion of resources from the traditional academic high school program. These elitist goals appeared to be tied to a view of technical education as a targeted program for the children of the working class which must not be allowed to threaten the privileged status of the city's collegiate institute.

Alison Taylor ${ }^{5}$ has connected the drive for state-supported technical education 
in secondary schools to a crisis in industrial capitalism marked by technological change, profit instability and labour-management conflicts. Business groups such as the Canadian Manufacturers' Association supported technical education as part of a national industrial policy, while labour representatives such as the Trades and Labour Congress endorsed it as a means of encouraging upward social mobility for workers and their families. She noted the key interplay of interest groups, including a split within the ranks of educators themselves, between traditionalists and progressives. Harry Smaller ${ }^{6}$ has noted the conflicted origins of technical and vocational education in Ontario, as elsewhere, and suggested that the evidence is just as strong for viewing the innovation as a means of keeping the workers in their place as it was a means of promoting their upward mobility. In so doing, he drew upon the work of Aaron Benavot, ${ }^{7}$ who classified scholarly explanations for the rise of vocational education in a three-fold schema. The "technical-functional" argument accepts that demands for skilled workers in industry encouraged the growth of education that could provide skills and training for an effective labour force. A second perspective, the "integrationist" model, posits that vocational education was advanced as a means both to provide opportunities for, but also to socialize workers to their new role as producer-citizens in a changing economy. The "neo-marxist" explanation suggests that technical and vocational education was a class-based solution advanced by capitalist interests to provide suitably trained and socialized labourers without challenging the basic assumptions of capitalism itself.

Turning to some of the more influential American studies on the rise of technical education, a good place to begin is with the work of David John Hogan on the "triumph of vocationalism" in the schools of Chicago in late nineteenth and early twentieth centuries. He depicted advocates of vocational training as emphasizing the role of publicly-funded schools to prepare working-class students for their future as industrial-era workers, even more than the schools' more traditional civic role of preparing them to become citizen-voters. ${ }^{8}$ The evocative title of H.A. Kantor's study of vocational reform in California schools during the same era, "Learning to Earn," underscores his central theme. While he questioned the long-term effectiveness of their efforts, Kantor concluded that most vocational reformers sincerely believed that using the schools to prepare students for the job market would benefit both the economy and the students themselves. ${ }^{9}$ Basing conclusions primarily on a study of an elitist Philadelphia public secondary school, David Labaree noted the contradictory aspects of that ubiquitous American institution, the comprehensive high school, with its multiple streams and programs. Here the goal of education for all clashed with the desire to enhance individual status through the attainment of unique scholarly credentials. In social class terms, the altruistic desire to elevate the working-class poor threatened the relative privilege of the middle classes. ${ }^{10}$ More recently, Grubb and Lazerson have linked the rise of vocationalism in the developing American high schools to something even grander, which they have dubbed the "Educational Gospel." By this they mean the belief that educational reform can lead to economic, social and individual salvation. For a century now, they assert, the means of attaining this lofty goal has been the transformation and maintenance of public education as a 
system wherein schools primarily prepare students for occupational vocations. In the early years of the twentieth century, this meant "adapting schooling to the demands of an industrial economy." 11

This brief overview of academic perspectives on the rise of secondary-school technical education sets the stage for the specific consideration of two representative case studies in Ontario: the pre-war Toronto Technical School, and the inter-war Windsor-Walkerville Technical School. After briefly looking at the origin of each school, we will re-visit the general discussion on the goals and impact of this significant educational innovation: the independent technical school.

\section{Origins of the Toronto Technical School}

It is important to understand the fundamental ways in which Ontario and Toronto were changing in the latter part of the $19^{\text {th }}$ century. A predominantly rural and agricultural province was moving rapidly along the twin tracks of urbanization and industrialization. The city of Toronto grew quickly from a population of 59,000 in 1871 to 181,000 in 1891 , and would continue this dizzying pace into the $20^{\text {th }}$ century, reaching 526,000 by 1921 . Toronto's impressive growth was based on a combination of secondary manufacturing, financial services, and commercial trade, supplemented by its role as the administrative centre of the province. Within industry, the trend was inexorably toward larger factories utilizing ever more sophisticated machinery powered largely by electricity. While Canadian industry was sheltered from competition behind National Policy tariffs, still there was recognition of the need to keep up with potential trade rivals in Europe and America. One aspect of the competitive arsenal was a properly-trained labour force.

Serious discussions to establish a permanent institutional setting for the provision of courses in various technical skills in the city of Toronto emerged in the late 1880s. At a time when only a small minority of students even entered secondary schools, and far fewer graduated, it was not clear if day classes or evening classes would prove the more beneficial. Furthermore, should such courses be specific to particular jobrelated skills, or more generic in nature, and include general instruction in science, mathematics and other courses more associated with a classic liberal education? Such issues were debated in the context of hard economic times. After the railroadbuilding boom of the early 1880s, Canada suffered through nearly a decade of economic stagnation. Emigration exceeded immigration in these years, as enterprising Canadians flocked to the fertile farmlands and bustling cities of the American West and Midwest. With no engine to pull it along, the Canadian economy lurched forward unevenly. Worker layoffs were common, and business failures not unknown. ${ }^{12}$ The combination of economic uncertainty and emerging technological change led some voices in industry, organized labour and civic government to seek to address a few common concerns through public education.

Late in 1888 the mayor of Toronto, E.F. Clarke, initiated a dialogue with the provincial Minister of Education, George Ross, concerning the augmentation of educational programs related to technical education. ${ }^{13}$ Then in February, 1889, Toronto's 
city council established a committee to look into the matter of evening classes for workers interested in technical education. At Ross's initiative, legislation was passed to permit the Free Library Board in Toronto to offer such courses. This latter body declined to act, however, and so the city council asked John Galt ${ }^{14}$ to prepare a report on the matter. He advocated the establishment of a central technical school for day and night classes, as well as branch schools spaced throughout the city. In July of 1890, the council endorsed a report supporting the establishment of "classes at which artisans can be taught the scientific principles and laws which underlie the handicrafts and industries in which they are engaged." ${ }^{15}$ The city's municipal government lacked a legislative mandate to proceed, but this was provided in the spring of 1891 when the provincial legislature amended the Municipal Act to authorize interested municipalities to establish "schools for the training and education of artisans, mechanics, and working men." 16 Subsequently, in December, 1891, Toronto's city council passed a by-law to establish a single technical school, complete with its own board, which would be funded from the municipal coffers.

The first evening classes began in January 1892 in a makeshift site at St. Lawrence Hall. Almost immediately, the new school was faced with the problem of over-crowding, and it relocated to modestly improved quarters at Wycliffe Hall. Under the leadership of the first principal, John A. Duff, course offerings included mathematics, chemistry, physics, geometry, mechanics and drawing. At his commencement ceremony speech in the fall of 1892, Principal Duff sounded enthusiastic and hopeful about the future of the school.

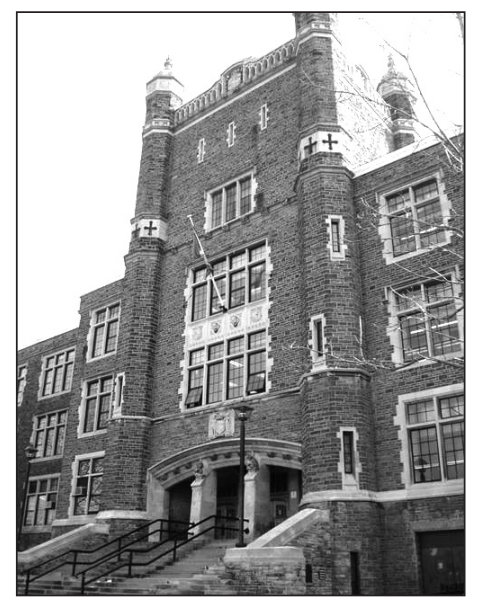

Toronto Technical School (2006) - courtesy of author

There is every reason to hope that the coming year will be still more successful, and that the Toronto Technical School will rapidly become a great power for the dissemination of scientific knowledge and habits of correct thought. With additional teaching power we have been able to make the course of study more comprehensive. Trigonometry will be taught twice a week instead of one, which was all the time we were able to devote to it last year, and if necessary the classes in Arithmetic and Mensuration will be sub-divided. Arrangements have been made for three classes per week in Chemistry and Physics, which will enable us to provide a tolerably complete course in Electricity - that mysterious element which seems destined to usher in a new era of civilization. There is thus provided for the current year the following distinct courses of study and Mathematics, including Arithmetic, Mensuration, Algebra, Euclid, Trigonometry, Practical Geometry, Physical Geometry, Mechanical and Architectural Drawing; Mechanics including Statics, Kinematics and 
Dynamics; Chemistry and Physics, including Hydrostatics, Heat, Light, Sound and Electricity. ${ }^{17}$

The emphasis was upon the practical application of these subjects in the work world. Enrolment topped 600 students by 1894, and was double that again by 1900 . Clearly there was a demand for these types of classes, though it should be noted that students in these evening courses were not required to pay fees. Moreover, as reported by the second principal, E.B. Merrill, in 1894, problems of transportation accessibility limited average attendance to one-half of the overall enrolment. ${ }^{18}$ One additional boost to registration occurred in 1896 when the Toronto Technical School Board opted to open a special class for female students in domestic science, ${ }^{19}$ which proved popular and thereby ironically contributed to the problem of overcrowding.

The Technical School Board continued to press the Toronto City Council for a permanent solution to the dilemma of cramped quarters. In a period of hard times and tight budgets, the city's municipal leaders were reluctant even to continue their modest grant of a few thousand dollars, which alone kept the school's doors open. While the growing expense of the technical school presented a challenge for city council it was difficult to deny the efficiency of the school. On December $19^{\text {th }} 1896$ the Globe and Mail reserved its entire front page to tout the success of the Toronto Technical School. In this feature article it was noted that the school was entirely funded by the city and received no money from the Ontario Department of Education. The technical school board structure and members were described in detail. The board was also lauded for the management of funds, noting that the high schools were run at a cost of $\$ 30$ per student while the Toronto Technical School ran at a cost of $\$ 6$ dollars per student. Even when the school was investing heavily in equipment during its first years the school still managed to run at a cost of $\$ 31$ per student. The article concluded by stating that "If Canada is to compete in foreign markets her mechanics must be as skilled and as well educated as those of other nations; and it is for the purpose of thus educating the mechanic in this city that the Toronto Technical School was established and judging by the success it has attained it is admirably discharging the duty for which it was ordained." 20

With the growing popularity and recognition of the Toronto Technical School the provincial government made its first step toward financial supporting technical schools. In 1897 it passed new legislation, "An Act Respecting Technical Schools," which promised a measure of grant money, provided the recipient board met certain conditions, the chief of which was a permanent and appropriate site. The standoff between the school board and city council continued though, until a notice of eviction from Wycliffe Hall brought matters to a head. Negotiations to purchase the Toronto Athletic Club occupied several years, however, before all the objections were overcome. Advocates for the school took heart from the remarks of Principal McMaster at the end of term in December 1898, as he recounted a tale of progress in enrolment, program diversification and course completion that had been accomplished in only seven years. ${ }^{21}$

The popularity of the evening course offerings led to the addition of day classes, 
accompanied by modest tuition fees, in 1901. By this time, voices from within and without the educational establishment were beginning to advocate both the extension of technical education to the mainstream high schools, and the establishment of a single board of education for Toronto. The new principal of TTS, William Pakenham, provided a written report in 1902 which demonstrated that the Toronto Technical School was exceptionally cost effective, in comparison with similar schools in the United States. ${ }^{22}$ When City Council attempted to cut the Technical School's operating grant, the Canadian Manufacturers' Association sent a deputation to City Hall to oppose the move. ${ }^{23}$ Spokespersons for organized labour in Toronto were similarly outspoken in their support of the school. However, its ultimate fate lay in the hands of the provincial government, which introduced legislation in 1903 to amalgamate the public, high and technical school boards in Toronto. ${ }^{24}$ In return for more assured funding, the independent technical school was about to lose its hard-earned autonomy.

The first meeting of the new school board was held in January, 1904. Later that year, the name of the school was formally changed to the Toronto Technical High School. It continued to attract a large enrolment, and by 1908 it was the largest secondary school in Toronto, with 700 day students and 40 teachers. ${ }^{25}$ Finally, in 1915 , the school moved to a permanent location in the core of Toronto, occupying a magnificent building constructed at a cost of $\$ 2,000,000$, under the name of Central Technical School. ${ }^{26}$ "In its first decade and a half of existence, it had demonstrated the viability of a stand-alone secondary school focused on technical education in Toronto. But, would its example be transferable to other urban centres in Ontario?"

\section{Structural Changes in the External Environment}

Before turning to a consideration of the Windsor-Walkerville Technical School, it is imperative to take note of several key changes in the politico-administrative environment of Ontario. In 1904, the provincial Department of Education issued a revised set of regulations concerning secondary education in the province. No fewer than seven different high school programs were approved as the basis of study and eventual graduation: general, commercial, manual training, household science, agriculture, university matriculation and normal school (teachers' college) entrance. Only the latter two were designed to prepare students for post-secondary schooling. The others were intended to prepare their pupils for paid employment in the job force, or in the case of household science, unpaid labour in the home. School boards were slow to exploit the opening for program innovation which the Department of Education had created, however. Some collegiate institutes added courses in the practical areas, but most were reluctant to incur significant up-front costs, in the absence of provincial funding incentives. ${ }^{27}$

Both the Canadian Manufacturers Association and the Trades and Labour Congress lobbied Queen's Park for a more tangible commitment to technical education. The first step was the election in 1905 of a new Conservative government headed by James Whitney which, despite the party name, included a number of 
progressive-minded members within its ranks. The Superintendent of Education, John Seath, was asked in 1910 to conduct an investigation of various approaches to technical instruction in the United States and Europe. His report, "Education for Industrial Purposes," was issued in December, 1910, ${ }^{28}$ and its recommendations formed the basis for the Industrial Education Act, a landmark piece of legislation that established a new set of parameters for the province. For students unlikely to pass the rigorous set of high school "entrance exams," boards were empowered to establish industrial schools that would offer vocationally-targeted courses. In addition, the boards were encouraged to establish stand-alone technical high schools, as well as new technical departments in existing secondary schools and collegiate institutes. Evening classes for individuals already in the work force received official support, as well, and to ensure a close connection between course offerings and local employment opportunities, each technical school was to set up an advisory committee representing business, labour and other local interests. Most importantly, the provincial government promised to provide assured funding for both capital and operating costs. ${ }^{29}$ Across Ontario, small and medium-sized cities began to join the ranks of the early leaders - Toronto and Hamilton — in establishing full-fledged technical schools.

At the same time, and in response to similar pressures from big business and organized labour, the federal government took steps to encourage a more focused approach to the educational preparation of a skilled labour force. As long ago as 1889, the Royal Commission on the Relations of Labour and Capital in Canada had urged that "more attention must be given to training our people to become artistic and skilled workmen." 30 For two decades, the national government had shied away from direct involvement in this policy area, since education had clearly been allocated to the provincial governments by the British North America Act of 1867. About the same time that Seath was commencing his investigation of technical education, a new Minister of Labour was appointed in Ottawa. William Lyon Mackenzie King was quietly supportive of the technical training issue, and worked behind the scenes to convince the prime minister, Sir Wilfrid Laurier, to authorize a formal inquiry into the topic. In 1910 a new Royal Commission was established to investigate "Industrial Training and Technical Education." Three years later, it presented its report to a Conservative government headed by Robert Borden. Chaired by James Robertson, principal of Macdonald College in Quebec, the commission recommended that technical education should remain a provincial responsibility, but strongly advocated federal funding assistance on a shared-cost basis to encourage the development of industrial training at the secondary school level. The report gathered dust for more than five years, but once the war was over, its recommendations were brought out again as part of a postwar reconstruction program. Strong support from the Union Government's Minister of Labour, Senator Gideon Robertson (a former railway union leader), was helpful, and in the Spring of 1919, the Technical Education Act was quickly approved by a Parliament pre-occupied by labour unrest in Winnipeg. Ottawa undertook to provide $\$ 10$ million (a substantial sum at the time) over a ten-year period to support secondary-school technical education, with 
the funds to be disbursed on a shared-cost basis. ${ }^{31}$ For provinces that lacked a foothold in providing vocational education the new law was not terribly helpful, but in industrializing Ontario, it was welcomed with open arms. In light of this new federal funding, Queen's Park was prepared to subsidize capital expenditures on technical education up to 50 per cent.

The last piece of the puzzle fell into place when the Ontario legislature passed the Adolescent School Attendance Act in 1919, with its main provisions to take effect by 1921. Under this measure, the age of compulsory schooling was increased from 14 to 16. At a stroke, thousands of young Ontarians who had been accustomed to the pattern of leaving school to seek employment at the end of elementary school now were required to enrol in high school. At the same time, tuition fees for secondary schools were abolished across the province. ${ }^{32}$ School boards scrambled to provide a range of course offerings to the newly-enlarged student body, most of whom had little interest in the rigid, traditional program symbolized in the very name of the collegiate institutes. Technical education vied with commerce, agriculture and domestic science as the new growth areas among high school courses offered in the 1920s. In 1901, there had been one technical school in Ontario - the Toronto Technical School. Twenty years later, when the new school-leaving age of 16 took effect, there were 13 . By 1935, there were 63 across the province. ${ }^{33}$

One of the new technical high schools appeared in London, Ontario. With a population approaching 50,000 by the end of the Great War, it had experienced significant growth in factory-based manufacturing in the first two decades of the twentieth century. The lone high school, London Collegiate Institute (L.C.I.), was becoming increasingly crowded by this time, and public-minded citizens lobbied for a second one - though there was disagreement as to its character. Should it be another collegiate institute, or a technical school? The old guard on the city school board had voted down a resolution to establish a technical high school in 1911, but night classes in technical subjects began in January, 1912. A day school to offer similar instruction, albeit in temporary quarters, was launched in September, 1912, under the name of the London Industrial and Art School. A coalition of boosters that included the city Board of Trade, the local branch of the Trades and Labour Congress, and a few educational reformers had overcome elite resistance to the venture, but if it were to become a permanent feature, the new school required a suitably-designed building. Ontario's Director of Technical Education, Walter Merchant, was a former principal of L.C.I.; he urged the London school board to fund and build an acceptable permanent structure for the school, even threatening to withhold the provincial grant unless such action was taken. Amidst considerable grumbling from proponents of a second collegiate institute, the local school board succumbed to provincial pressure, and the newly-constructed building was officially opened in January, 1919. It was soon granted full high school status, and officially became the London Technical High School. Enrolment did not take off, however, until the full effects of the new Attendance Act were felt. The 196 day students of 1921 became 663 in 1923 and 957 by $1926 .{ }^{34}$ 


\section{Origins of the Windsor-Walkerville Technical School}

Toronto was at the centre of Ontario - not just geographically (at least in terms of southern Ontario), but also politically, economically, and culturally. Windsor, by contrast, has always existed on the periphery. In terms of economic geography it is, and was at the turn of the $20^{\text {th }}$ century, an industrial suburb of Detroit - at that time just beginning to make its way to industrial prominence as the unchallenged Motor City of America. Incorporated as a city only in 1892, with a population at that time of 10,500, Windsor symbolized the second layer of Ontario urban centres - those which aspired to economic growth and industrial development, but which lacked the financial and political clout of a Toronto, Hamilton or Ottawa. After a stagnant decade to end the $19^{\text {th }}$ century, the Border Cities - consisting of Windsor and three neighbouring municipalities: Sandwich, Walkerville and Ford City — enjoyed a period of accelerating population growth and industrial development during the next 20 years. The decision of the Ford Motor Company to establish a branch plant on the Canadian side of the Detroit River in 1904 symbolized the area's attractiveness for American enterprises seeking to enter Canadian and British imperial markets. The population of greater Windsor grew to 23,000 in 1911, and 56,000 ten years later. In addition to the growing employment opportunities on their own side of the border afforded by branch plants, an estimated 15,000 Windsor-area residents held jobs in Detroit's offices and factories by the 1920s, travelling by ferry across the river each day until the Ambassador Bridge, and the international motor-vehicle tunnel, were opened in 1929 and 1930, respectively. ${ }^{35}$

Following up on the Seath Report, F.P. Gavin, principal of the region's lone academic high school, Windsor Collegiate Institute, moved to offer evening classes in industrial training in $1913 .{ }^{36}$ These proved so popular that two years later the citizens of Windsor voted to approve an addition to their high school to accommodate vocational courses for day students. ${ }^{37}$ The school's new technical wing was opened in 1917, at which time daytime classes in vocational subjects (among them auto engine management) for boys and household arts (domestic science) for girls were added. ${ }^{38} \mathrm{~A}$ year later, a notice in the local newspaper announced the resumption of "industrial night classes" for October, noting that some 600 pupils had been enrolled the previous year. The actual courses to be offered had been decided upon at a meeting of "the advisory industrial committee of the Board of Education." Specific classes mentioned included cooking for women, as well as "mechanical and architectural drawing, electrical engineering, sheet metal working, automobile mechanics and like subjects" for men, and English and arithmetic "for foreigners and beginners." So popular were the evening courses that two elementary schools, one Catholic and one public, were to be used as instructional sites in addition to the collegiate institute. ${ }^{39}$

While the Armistice in Europe was welcomed joyfully back in Canada, the end of the war brought with it a sharp economic downturn. Hundreds of thousands of overseas troops had to be re-integrated into the peacetime economy, and domestic industries needed to re-tool from military to consumer production. At the same 
time, continuing high prices for basic household staples combined with the uncertainty caused by layoffs to produce widespread labour unrest. The confrontational malaise was most vividly evident in Winnipeg, Manitoba, where a general strike paralyzed the city for several weeks, but everywhere across the country, the end of the war ushered in hard economic times. ${ }^{40}$ Windsor was no exception. The federal legislation passed in 1919 to subsidize the construction of technical schools created an opening for those who had long favoured an expansion of such courses in secondary-level education. A survey was conducted in the Border Cities region to determine the need for such a school, and it revealed a potentially substantial clientele. ${ }^{41}$ By this time F.P. Gavin, the former principal of the local collegiate institute, had moved to the provincial Department of Education as the Assistant Director of Technical Education. ${ }^{42}$ While the case for building a technical high school in the Windsor area was strong on its own merits, it certainly did not hurt to have the individual affectionately known as the "founder of technical education" in the Border Cities $^{43}$ strategically placed in the decision-making hierarchy at Queen's Park.

Authorization was duly given by the Ontario Department of Education in 1921 for the construction of a new vocational high school to be known as the WindsorWalkerville Technical School. Total cost of the building was just under $\$ 800,000$, and the provincial government (using federal funds) would assume responsibility for 50 percent. ${ }^{44}$ The municipal governments of the City of Windsor and Town of Walkerville jointly provided the property for the new school. ${ }^{45}$ W.D. Lowe, Gavin's successor at Windsor Collegiate Institute, was hired as the school's first principal. He reported to a newly-created board which consisted of two representatives each from the Windsor public board of education, the Windsor separate board of education, the Walkerville public board of education, the Walkerville separate board of education, the Trades and Labour Council, and the Chamber of Commerce. ${ }^{46}$ The new building was handsomely designed in Tudor Gothic style, with twin towers facing spacious Giles Boulevard. There were nearly 50 classrooms, as well as an auditorium, a gymnasium, a cafeteria, shops, labs and offices ${ }^{47}$ in the impressive structure. For its day, the new

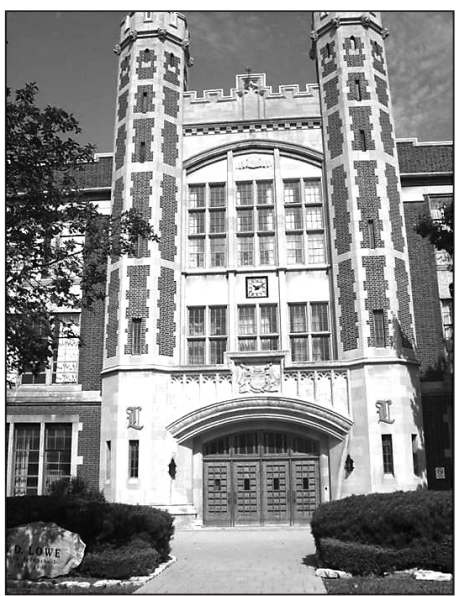

W.D. Lowe Technical School (2010) - courtesy of author technical school was superbly equipped.

Formal classes at the Windsor Walkerville Technical School began on September 4, 1923. Initial enrolment was 573 students, both male and female. ${ }^{48}$ In addition to the principal, W.D. Lowe, the staff consisted of 25 teachers and a school nurse. ${ }^{49}$ Late in August, Principal Lowe had released a statement to the press, outlining some basic information about the new institution: 
The Technical School ranks as a high school. The textbooks are similar to those used in the high schools, the courses of study on the academic side are much the same and there is the same requirement for entrance. The Technical School, however, in addition to affording a general education, will give training in vocation [sic] to those boys and girls who will find their employment on leaving school in business, in industry, or in the home. As the Technical School courses are designed for those pupils who will not attend the universities, but as has been said will find their vocation in business or industry, no attempt will be made to prepare pupils for matriculation and the languages will not be studied .... Each pupil must take all the subjects in his course, academic as well as vocation.

Lowe went on to explain that the school would have two main departments: commercial and technical. With respect to the former, the commercial departments at Windsor Collegiate Institute and Walkerville High School were being transferred to the new school, thus ensuring a robust enrolment right from the start. ${ }^{50}$

Principal Lowe described in more detail the makeup of the two curriculum streams:

In addition to receiving training in the general subjects of the High School courses, pupils in the commercial courses will be prepared for various positions in the business world - bookkeeping and accounting, stenography, typing and secretarial work, the operation of business machines, and in any other position where a knowledge of office practice is required.

While Lowe did not stipulate one gender or the other for the commercial program, he was purposely gender-specific in describing the technical classes:

The technical course for boys combines a general education in the subjects of English, mathematics, science, history and geography with such a varied vocational training as will guide them in their choice of employment, and give them a wide insight into industrial processes.... The woodworking and machine shops, foundry, automobile, applied electricity, plumbing and sheet metal shops indicate the variety of work taken up.

Contrast that description with the principal's explanation of technical classes for girls:

Similarly, the technical course for girls combines a general high school education with vocational training in the various subjects classed as household arts - cooking and diet, millinery, dressmaking, including choice and value of fabrics, and home decoration.

The influence of domestic science would also be felt in the commercial courses: 
As the ultimate destiny of the majority of girls who choose a business course will be the home, a generous allotment of time is allowed in the business courses to the subjects of household arts.

Principal Lowe was not clear on what the male students in the commercial stream would take in lieu of "household arts." 51

Clearly the preferred route into the new technical high school was to pass the province- wide high school entrance exam. However, Lowe was able to offer another option, a "prevocational" year, for those who lacked that pre-requisite:

Sometimes boys and girls on account of their age, size or for other reasons, become dissatisfied with the grade schools before passing the entrance examination to high school. Realizing this fact and unwilling that any of our boys or girls should be thrust into the ranks of a wage-earner at too early an age, and without adequate training for making a livelihood, the Department of Education permits such pupils to be admitted to the Technical School at the discretion of the principal provided they have gained fourth book standing and can furnish adequate reasons for not continuing at the grade school.

Lest the potential applicants be tempted to slack off in elementary school, the principal added an important caveat. "Experience has shown," he advised, "that pupils entering Technical School with entrance standing make much better progress than those who have not reached that grade." 52

It was now provincial policy that the general high school program was four years in length, notwithstanding the fact that the minority headed for university would be taking a fifth year. As an enticement for exceptional students, Lowe noted that "opportunity will be given pupils who show special aptitude to gain their diplomas in three years." On the other hand, he was cognizant of the fact that many of his incoming students would be quitting school once they turned 16:

It is realized ...that many pupils may find it impossible to attend for more than one or two years. Accordingly the courses are so arranged that even the pupil who can attend only one year will in that time acquire some skill that has a recognized market value. Pupils will find attendance well worth while even though they may not be able to complete their course. ${ }^{53}$

The same Adolescent School Attendance Act which was creating much of the new enrolment for Windsor Walkerville Technical School by bumping the legal minimum age for school attendance from 14 to 16 would also permit a noticeable dropout rate after two years of a four-year program. The principal sought to re-assure students, and their parents, that the one or two years spent at his school would still be productive ones.

The new technical high school proved to be a runaway success. Enrolment rose steadily, to 800 day and 1700 evening students in 1927, and 1150 day and over 2000 
evening students two years later. ${ }^{54}$ By this time, it was the largest high school in the city and county. A large addition to the building was completed in $1931 .{ }^{55}$ Yearbooks of the time indicate a broad-based extra-curricular program similar to other high schools of that day, featuring athletic teams for males and females, a debating team, a school orchestra, a student council and a cadet corps. ${ }^{56}$ By all the evidence, school spirit was high. This was fortunate, because when the Great Depression of the 1930s hit, it dealt the Border Cities a particularly cruel blow. Automobiles, the consumer rage of the 1920s, were a discretionary item for most Canadian families, and so new car and truck purchases nosedived. The auto-related factories and shops in the Windsor area were hard hit.

Unemployment was widespread, property taxes went unpaid, and municipal governments defaulted on their debentures. A new technical high school in the 1930 s would have been unthinkable. But, after having proved its worth through the Twenties, any move to disband "Windsor-Walkerville Tech" in the Thirties was simply beyond the pale. For the Border Cities community, it had quickly earned its spurs. This was underlined by the fact that the Ford Motor Company of Canada had begun as early as the late 1920 s to give hiring preference to WWTS graduates. ${ }^{57}$

\section{Comparing the Two Schools}

There are both similarities and differences in the origins of Toronto Technical School and Windsor Walkerville Technical School. The former was the pioneering institution of its kind in Ontario, while the latter was the first such school in the WindsorEssex region. Each started up in the midst of harsh economic times, but in the case of the Toronto school, the lean years continued for most of the decade before giving way to the so-called Laurier boom, while for the Windsor school, the postwar recession was sharp but short, and quickly gave way to the prosperity of the Roaring Twenties, fuelled locally by illicit rum-running ${ }^{58}$ in addition to the automobile craze. Funding for Toronto Technical School was a perpetual problem, until the opening of a permanent site for the renamed Central Technical School in 1915, a full quarter-century after its start-up, whereas Windsor Walkerville Technical School, benefiting indirectly from the federal law of 1919, as well as provincial support, began its existence in a newly constructed, well-equipped structure. Both schools enjoyed broad-based local support that included business and labour leaders, civic officials and a sympathetic press. Technical education boosters equated the new schools with economic development and employment opportunities in a period of rapid technological and social change.

From the beginning, each institution had female as well as male students, though the former tended to be clustered in domestic science and commercial subjects, reflecting the prevailing "separate spheres" mentality of the day. ${ }^{59}$ Evening classes were a significant phenomenon in both schools, indicative of the pragmatic goals of many of the students seeking to upgrade their level of training, and thus employability. The Windsor school's enrolment benefitted immediately from the provincial law which had raised the minimum school leaving age to 16 in 1921, but the degree of interest 
in evening classes at Windsor Collegiate Institute prior to that change would seem to indicate it was but one factor among several. The Windsor principal's determination that his new Technical School would be accepted as the equal of other high schools in the Border Cities region demonstrates clearly that, though the mission of the new school was to prepare its pupils for their future vocations, whether in the paid labour force or in the home, nonetheless it was a school with standards that provided general academic education as well as specific skills training. It was not to be a mere holding-pen for difficult-to-teach students whose needs were not met elsewhere in the school system. In this quest W.D. Lowe appears to have been successful, for the school which would eventually bear his name quickly acquired an enviable cachet in the blue-collar-dominated city of Windsor which lasted for most of the $20^{\text {th }}$ century.

What can be firmly concluded about the appeal of technical education in Ontario three generations ago? We might begin by identifying the factors in these case studies that led to success in establishing a thriving technical high school, in urban jurisdictions where the elitist collegiate institute designed to prepare a small minority of students for university and eventually a profession had been the accepted norm. Among the determining factors for success was the existence of a local consensus among community leaders from business and industry, organized labour, the municipal government and the press - that the provision of practical courses in technical education was a desirable goal. Add to this the articulate support of at least some local educators, and a sympathetic ear from the more senior levels of government, and the chances of success improved significantly. The impact of hard economic times should not be minimized. Utilizing publicly-funded schools to train a skilled labour force which might attract investment and thus create jobs seemed like a sensible plan for economic recovery that appealed to multiple stakeholders: capital, labour, civic boosters and concerned parents. Providing some structural mechanism, such as an advisory council composed of representatives of these same stakeholders, also acted to keep the school in touch with the needs of its surrounding community. And finally, the inclusion of female as well as male students provided enrolment stability, even if the prevailing values of the day tended to herd those female students into domestic science and commercial studies.

While the point of this comparative investigation into the origins of Toronto Technical School and Windsor Walkerville Technical School was not to declare winners and losers in the debate between Benavot's "technical functional" versus "integrationist" explanation for the rise of technical education in Ontario's secondary schools, it must be said that the classic interpretation of Robert Stamp holds up rather well. Economic motives, whether collective in the case of business interests and labour unions, or individual in the case of students themselves and their parents, do seem to explain much of the impetus for the apparently radical innovation of high schools organized around the acquisition of practical, job-related skills rather than the traditional liberal arts rationale which continued to dominate the established collegiate institutes. In the United States the solution was the composite or comprehensive high school, which sought to offer something for everyone, all under one roof. Significantly, during the years covered in this study, both TTS and WWTS were 
deliberately designed as an alternative to the academic high school. Once provided with adequate funds and housed in suitable stand-alone buildings, they became elitist in another way, distinguished by the recognized quality of their programs, facilities and graduating students.

\section{Notes}

1 For a classic study of these changes in the American setting, see Marvin Lazerson, Origins of the Urban School: Public Education in Massachusetts, 1870-1915 (Cambridge, Mass.: Harvard University Press, 1971), esp. 179-201.

2 See Robert M. Stamp, "Urban Industrial Change and Curriculum Reform in Early Twentieth Century Ontario," in Studies in Educational Change, eds. Richard D. Heyman, Robert T. Lawson and Robert M. Stamp, (Toronto: Holt Reinhart \& Winston, 1972), 9-87; also Robert M. Stamp, The Schools of Ontario, 1876-1976 (Toronto: University of Toronto Press, 1982), 51-96.

3 T. R. Morrison, "Reform as Social Teaching: The Case of Industrial Education in Ontario, 1870-1900," in The Journal of Educational Thought 8, 2 (1974): 87-110.

4 Ivor F. Goodson \& Ian R. Dowbiggin, "Vocational Education and School Reform: The Case of the London (Canada) Technical School, 1900-1930," in History of Education Review 20, 1 (1991): 39-60.

5 Alison Taylor, "Education for Industrial and 'Postindustrial' Purposes," in Educational Policy 11, 1 (1997): 3-40.

6 Harry Smaller, "Vocational Education in Ontario Secondary Schools: Past, Present - and Future?," in Integrating School and Workplace Learning in Canada: Principles and Practices of Alternation Education and Training, eds. Hans G. Schuetze \& Robert Sweet, (Montreal \& Kingston: McGill-Queen's University Press, 2003), 95-134. Significantly, Smaller notes the overall decline in student enrolment in technical and vocational programs across Canada since the middle of the $20^{\text {th }}$ century as parents and pupils perceive less value in this curriculum than the standard academic curriculum.

7 Aaron Benavot, "The Rise and Decline of Vocational Education," in Sociology of Education 56, 2 (1983): 63-76.

8 David John Hogan, Class and Reform: School and Society in Chicago, 1880-1930 (Philadelphia: University of Pennsylvania Press, 1985), esp. Chapter 4 "The Triumph of Vocationalism," 138-193.

9 Harvey A. Kantor, Learning to Earn: School, Work, and Vocational Reform in California, 1880-1930 (Madison Wis.: University of Wisconsin Press, 1988), esp. the "Conclusion," 167-169.

10 David Labaree, The Making of an American High School: The Credentials Market and the Central High School of Philadelphia, 1838-1939 (New Haven, Conn.: Yale University Press, 1988) esp. 1-8.

11 W. Norton Grubb \& Marvin Lazerson, The Educational Gospel: The Economic Power of Schooling (Cambridge, Mass.: Harvard University Press, 2004), esp. 1-14.

12 See John T. Saywell, "The 1890s" in J.M.S. Careless \& R. Craig Brown, eds., Part One of The Canadians, 1867-1967 (Toronto: Macmillan, 1968), 112-14; see also Joseph Schull, Ontario Since 1867 (Toronto: McClelland \& Stewart, 1978), 140-56.

13 For a fuller account of the politics involved in the establishment of the Toronto Technical School, see Kathleen Y. Sharman "The Origins and Significance of the Toronto Technical School 1891-1904” (Master of Education Thesis, University of Windsor, 2006). 
14 John Galt was an alderman who was instrumental in shaping a curriculum for TTS that combined science with industrial art. His popular views earned him a place on the subcommittee for technical education.

15 Report No. 21, Appendix No. 299 of Minutes of Proceedings of the Council of the Corporation of the City of Toronto, 1890. City of Toronto Archives.

16 The Municipal Amendment Act, 1891, Statutes of the Province of Ontario.

17 Ontario Department of Agriculture, Province of Ontario, 1893. Annual Report of the Bureau of Industries. 1894. Warwick Bros. \& Rutter, Printers; Toronto Ontario., 42. http://www.archive.org/stream/annualreportbur02ontagoog (accessed on May 31, 2011).

18 See Oisin Patrick Rafferty, "Apprenticeship's Legacy: The Social and Educational Goals of Technical Education in Ontario, 1860-1911" (Doctoral dissertation, McMaster University, 1995), esp. Chapter Five, 215-57.

19 Ruby Heap, "Schooling Women for Home or for Work? - Vocational Education for Women in Ontario in the Early Twentieth Century: The Case of the Toronto Technical High School, 1892-1920," in Alison Prentice \& Ruby Heap, eds., Gender and Education in Ontario: An Historical Reader (Toronto, 1991), 195-243.

20 The Toronto Technical School" in The Saturday Globe, December 19, 1896, 1.

21 "Trustees Kick," Toronto Evening Star, December 22, 1898, 7.

22 William Pakenham, Report to the Toronto Technical School Board, 1902. Ontario Archives, RG2-42-0-6563, MS 5676.

23 "Manufacturers Protest," Toronto Daily Star, May 12, 1902.

24 An Act Respecting Boards of Education, 1904, Statutes of the Province of Ontario.

25 Stamp, 1972. op.cit., 68.

26 Stamp, 1982, op.cit., 83.

27 Stamp, 1972., 63-64.

28 R. M. Stamp, "John Seath: Advocate of Vocational Preparation," in Robert S. Patterson, John W. Chalmers \& John W. Friesen, eds., Profiles of Canadian Educators (D.C. Heath, 1974), 233-52.

29 Stamp, 1982, p. 82.

30 Cited in Robert Stamp, "Technical Education, the National Policy, and FederalProvincial Relations in Canadian Education, 1899-1919," in Canadian Historical Review LII, 4 (December 1971): 404.

31 Ibid., 404-23.

32 Stamp, 1982, 107, $110 \& 117$.

33 Marta Danylewycz, Nadia Fahmy-Eid \& Nicole Thiverge, "Domestic Science Education in Ontario, 1900-1940," in J. Donald Wilson, ed. An Imperfect Past: Education and Society in Canadian History (Vancouver: UBC, 1984), 102.

34 Goodson \& Dowbiggin, 1991

35 Neil F. Morrison, Garden Gateway to Canada: One Hundred Years of Windsor and Essex County, 1854-1954 (Windsor: Herald Press, 1954).

36 "F.P. Gavin Is Stricken," in Windsor Star, October 3, 1944.

37 W.D. Lowe Reunion Booklet, 1973. Tony Techko Papers, University of Windsor Archives. File 100, Box 4.

38 David Roberts, In the Shadow of Detroit: Gordon M. McGregor, Ford of Canada, and Motoropolis (Detroit: Wayne State University Press, 2006), p. 163.

39 "Night Classes To Be Organized In Windsor Schools," in Border Cities Star, October 7, 1918.

40 Roger Graham, "Through the First World War," in Careless \& Brown, The Canadians, 1867-1967, esp. 190-96; Joseph Schull, Ontario Since 1867, 225-34.

41 Lowe Reunion Booklet, 1973. Tony Techko Papers, University of Windsor Archives. File 100, Box 4. 
42 Morrison, Garden Gateway to Canada, 280.

43 "Gavin Is Stricken," Windsor Star, Oct. 3, 1944.

44 F.W. Merchant to George Courtenay, October 14, 1921. Board of Education Correspondence. Municipal Archives, Windsor Public Library. RG2 AV-2/66.

45 George Courtenay to the Mayor and Members of the City Council, October 20, 1921. Board of Education Correspondence. Municipal Archives, Windsor Public Library. RG2 AV-2/66.

46 WWTS Yearbook, 1926-27.

47 Lowe Reunion Booklet, 1973. Tony Techko Papers, University of Windsor Archives. File 100, Box 4.

48 Ibid.

49 The Towers - 25 th Anniversary Edition, 1947-48.

50 “Principal Outlines Technical Courses," Border Cities Star, August 23, 1923.

51 Ibid.

52 Ibid.

53 Ibid.

54 WWTS Yearbooks, 1926-27 \& 1928-29.

55 Morrison, Garden Gateway, 280

56 For more on the new teenage sub-culture of high school life, see Robert M. Stamp, "Canadian High Schools in the 1920s and 1930s: The Social Challenge to the Academic Tradition," CHA Papers 13, 1 (1978): 76-93; and Cynthia Comacchio, "Inventing the Extracurriculum: High School Culture in Interwar Ontario," in Ontario History XCIII, 1 (Spring 2002): 33-56.

57 Stamp, Schools of Ontario, 114.

58 For more on the impact of America's Prohibition laws on the Border Cities, see Marty Gervais, The Rumrunners: A Prohibition Scrapbook (Canada: Biblioasis, 2009).

59 For more on the impact of gender and class on the rise of commercial schooling as a distinct aspect of vocational education in Canada see Nancy S. Jackson \& Jane S. Gaskell, "White Collar Vocationalism: The Rise of Commercial Education in Ontario and British Columbia, 1870-1920," in Curriculum Inquiry (vol.17 no.2, Summer 1987), 177-201. 